\title{
BIOCOM PATIBLE GEL-LIKE FORMS OF DRUGS ON THE BASIS OF SOLUTIONS OF POLYSACCHARIDE CHITOSAN WITH ALCOHOLS
}

\author{
Marina Bazunova ${ }^{1, *}$, Luciya Sharafutdinova ${ }^{1}$, Anna Bazunova ${ }^{1}$, \\ Roman Lazdin ${ }^{1}$, Mariya Elinson ${ }^{1}$, Elena Kulish ${ }^{1}$
}

https://doi.org/10.23939/chcht12.01.043

\begin{abstract}
We propose an approach to the preparation of viscoelastic systems based on chitosan without crosslinking agents. It is the formation of an additional network of physical links by introducing a low molecular weight modifier - ethanol or glycerol. It turns out that gelation of chitosan in the solution is accompanied by the formation of additional meshes of physical links, nodes or aggregates of chitosan macromolecules formed in a mixed solvent of acetic acid-water-glycerol or acetic acid-waterethanol. It promotes an earlier formation of viscoelastic properties, which eventually leads to gelation at lower polymer concentrations than in the case of chitosan solutions without alcohol additives. The resulted gelled systems are characterized by good biocompatibility, and therefore can be used as polymeric forms of drugs.
\end{abstract}

Keywords: chitosan, gel, alcohols, viscosity, drugs.

\section{Introduction}

Nowadays, polymer gels are widely used as materials for biomedical applications, for example, as supporting and separating means for electrophoresis, gel permeation chromatography, as carriers for immobilized biologically active substances (BAS), materials for making prostheses, etc. [1]. The reason for such a wide and varied application of gels is their unique porous structure and high permeability for low and highmolecular compounds.

A very urgent problem is creation of gels for medical purposes with a given set of properties based on naturally occurring polymers such as chitosan (CHTZ) and its derivatives, which have biocompatibility and absence of toxicity. Polymeric gels may be used as transport forms of drugs for wound healing coating and implantable prosthetic devices [2-4]. Thus, there are some advantages of gels as wound-healing coatings, in contrast

\footnotetext{
${ }^{1}$ Bashkir State University

32, Zaki Validi St., 450076 Ufa, Republic of Bashkortostan

mbazunova@mail.ru

(c) Bazunova M., Sharafutdinova L., Bazunova A., Lazdin R., Elinson M., Kulish E., 2018
}

to conventional sorption bandages (gauze, cotton and gauze, nonwovens, or polymeric sponges), in which there is a dynamic equilibrium of concentration microflora on the boundary "bandage-wound". The advantages are plasticizing effect on wound tissue, softening of necrotic formations, facilitating of mechanical removal of devitalized tissue, preventing the development of infection of wound under scab. They create a moist environment optimal for normal regeneration on a wound. Due to the cooling effect of the gel dressings and, consequently, lowering the local temperature conditions of underlying tissues it is possible to hinder the development of purulent infection in a wound. The gel helps to eliminate exudate and suppress microflora [5].

Elastic and plastic (rheological) properties such as viscosity, yield stress, viscous modulus, elasticity modulus, and thixotropy show a number of indicators and quantitative parameters characterizing the processes associated with the production and use of polymer gels. In case of development of polymeric dosage forms, rheological parameters affect the indicators such as ease of use and dosing.

Chitosan is an associating polyelectrolyte, i.e. its macromolecules consist of a charged chain sector (hydrophilic blocks) and are distributed along the chain of hydrophobic groups - stickers which can be aggregated with each other and form thermoreversible links. These polyelectrolytes can form finite-size clusters and, in principle, physical gel [6]. However, it is impossible to obtain viscoelastic systems from chitozan apparently due to its polyelectrolyte nature (by dissolving in the most commonly used solvent - acetic acid).

The most common method of producing viscoelastic systems based on CHTZ and its derivatives consists in stitching their macromolecules with bifunctional crosslinking compounds, for example, glutaraldehyde [7]. However, the products of the interaction of glutaraldehyde with amino groups of CHTZ are Schiff's bases, which are quite toxic.

We chose the approach to the creation of viscoelastic systems based on CHTZ without crosslinking agents, comprising the formation of an additional network 
of physical links by introducing a low molecular weight modifier - ethanol or glycerol.

The selection of these data modifiers for the regulation processes of gelation of CHTZ solutions is due to the fact that glycerol is capable of forming intermolecular hydrogen bonds with macromolecules of polysaccharides. If we add ethanol, it causes deterioration of thermodynamic quality of the solvent relative to the polymer, which should lead to the increase in the degree of association of macromolecules in the solution, as polymer-polymer contacts become more possible than polymer-solvent ones.

Thus, the aim of this work is to determine the rheological characteristics of CHTZ solutions in the mixtures of acetic acid glycerol and different volumetric ratios of CHTZ solutions in water-ethanol mixtures of different volumes.

\section{Experimental}

We used CHTZ with $M_{m}=340 \mathrm{kDa}$ manufactured by JSC "Bioprogress" (Shchelkovo, Russia).

As the solvent of CHTZ we used $1 \%$ acetic acid; a mixture of $1 \%$ acetic acid with glycerol of 90:10, 80:20 and about $70: 30(\mathrm{v} / \mathrm{v})$ or mixtures of $1 \%$ acetic acid and ethanol of 90:10, 80:20 and about 70:30 (v/v).

Rheological measurements of CHTZ solutions were carried out using a modular dynamic rheometer HaakeMars III at $298 \mathrm{~K}$ under two modes - continuous displacement with the rates ranging from 0.1 to $100 \mathrm{~s}^{-1}$ and under the oscillation mode. Flow and viscosity curves were obtained by a continuous shear deformation mode at shear rates ranging from 0.1 to $100 \mathrm{~s}^{-1}$. The most Newton viscosity was the one determined at the rate of displacement equal to $1 \mathrm{~s}^{-1}$, the least Newton viscosity occurred at $100 \mathrm{~s}^{-1}$.

As the tests under the oscillation mode must initially be performed in the linear viscoelastic sphere, optimum values of the amplitudes corresponding to the constant values of the modules (linear viscoelastic region) were determined on the basis of correlations of storage units and loss of voltage amplitude obtained at a constant frequency of oscillation. If there are CHTZ solutions with concentrations ranging from 0.2 to $7 \mathrm{wt} \%$, then amplitude range is $0.1-10 \mathrm{~Pa}$ and the oscillation frequency is $0.1-$ $10 \mathrm{~Hz}$. This corresponds to the linear viscoelastic region i.e. modules are independent of the voltage amplitude.

To evaluate the biocompatibility of polymer in vivo gels and the formation of a coherent picture of the emerged biological response, a series of experiments on the implantation systems of CHTZ-glycerol- $0.1 \%$ acetic acid and CHTZ-ethanol- $0.1 \%$ acetic acid was conducted with the analysis of clinical indicators of blood in dynamics.
Outbred Wistar rats $(n=24)$ weighing 200-250 g were used for studying with observation of the requirements of the European Convention for the Protection of Vertebrate Animals used for experimental and other scientific purposes (Strasbourg, 1986) and the Federal Law of the Russian Federation "About protection of animals from cruel treatment" (01.01.1997). All animals were kept under standard vivarium conditions with free access to food and water. 4 groups of animals were formed (6 animals in each group). Polymer gels based on CHTZ-glycerol systems were hypodermically sewn into the animals of each group.

Sterile matrixes with the size of $5 \times 5 \mathrm{~mm}$ were hypodermically sewn in aseptic conditions into the withers of male rats of Wistar line, narcotized with airthiopental anesthesia. Operational field after mechanical depilation was handled with skin antiseptic "AstradezOP". After orientation of the samples hypodermic fat tissue was stitched by internal sutures of catgut thread. The skin was stitched by silk thread. Postoperative period consisted of treating a wound with "Astradez-OP" for 3 days and removal of skin sutures was done on the fifth day of the experiment. During the postoperative period, common reactions to these implants were not revealed. Thermometric indicators remained within the normal range; the body weight of all animals was stable. On the first, third, seventh, fourteenth, and thirties days of the experiment the blood in the tale was taken for the analysis of hematological parameters [8].

\section{Results and Discussion}

In this paper, as an approach to the regulation of gelation in CHTZ solutions we suggested the introduction of a low-molecular modifier in the solution - triatomic glycerin alcohol - capable of forming intermolecular hydrogen bonds with macromolecules of $\mathrm{CHTZ}$ or monohydric alcohol of ethanol degrading the thermodynamic quality of the solvent with regard to the polymer. It should lead to the increase of the degree of association of macromolecules in the solution as polymer-polymer contacts are more probable than the polymer-solvent ones [9].

Consequently, CHTZ solutions in aqueous acetic acid and mixtures of acetic acid-water-glycerol or acetic acid-water-ethanol can show us a different kind of structural organization and a kind of fluctuation polymer entanglements of macromolecules. It can obviously affect the gelling properties of forming systems.

We studied rheological behavior of the solutions of CHTZ in the mixture of acetic acid-water-glycerol of various volumetric ratios and found out the following results. The addition of glycerol in CHTZ-water-acetic acid is accompanied with a significant increase in 
dynamic viscosity almost in the entire range of studied polymer concentrations. Formation of mesh links in the presence of glycerol begins significantly at lower concentrations of CHTZ than in the case of aqueous polymer solutions of acetic acid (Fig. 1). For example, when we take glycerin of $20 \mathrm{vol} \%$ concentration we observe a significant increase of the dynamic viscosity with $0.8 \mathrm{wt} \%$ CHTZ concentration compared to the viscosity of aqueous polymer solutions; but if we take glycerin $(30 \mathrm{vol} \%)$ we get the same result with $0.2 \mathrm{wt} \%$ CHTZ concentration. Moreover, it is possible to note (Fig. 2 ) that the more the content of glycerol in the system, the greater the increase in the dynamic viscosity.

With 0.8 wt \% CHTZ concentrations at the ratios of $0.1 \%$ acetic acid:glycerol 70:30 (v/v) and 80:20 (v/v),

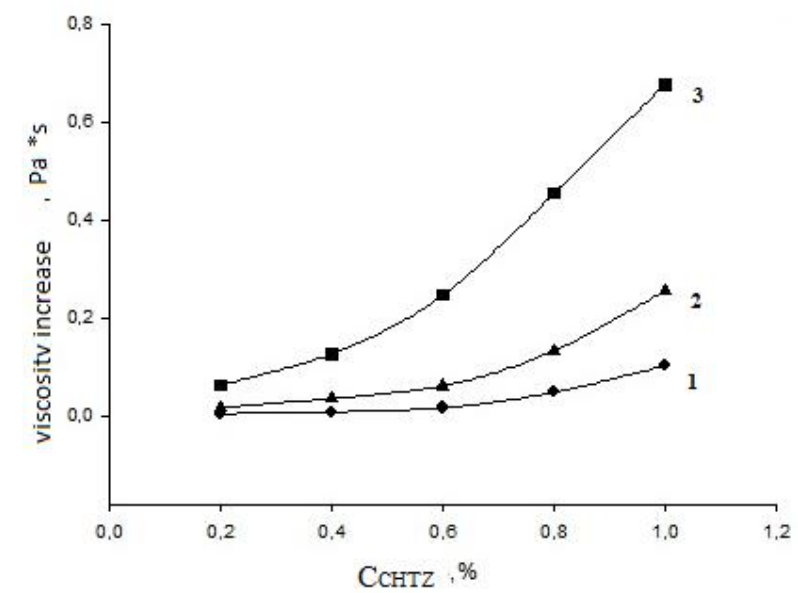

Fig. 1. Dependence of dynamic viscosity increase of CHTZ solutions in acetic acid-water-glycerol solutions in comparison with CHTZ solutions in acetic acid on the polymer concentration. Acetic acid concentration in the solution is $1 \mathrm{wt} \%$. The ratio 1\% acetic acid:glycerol (v/v) is 90:10 (1); $80: 20$ (2) and 70:30 (3) the elastic modulus of the studied systems is greater than the viscosity of the module and the systems become elastic and viscous (Table 1).

With polymer concentrations of $2 \%$ or more in CHTZ system, glycerol-1\% acetic acid becomes a thermoreversible gel.

The study of the rheological behavior of CHTZ solutions in the mixtures of ethanol- $0.1 \%$ acetic acid with different volumetric ratios showed the following results: firstly, if $\mathrm{CHTZ}$ concentration in the solution exceeds $2 \%$, the formation of gel systems takes place. It is characterized by the loss of strength, which indicates the formation of a solid network of physical intermolecular bonds. Furthermore, this elastic modulus exceeds the viscous modulus (Table 2).

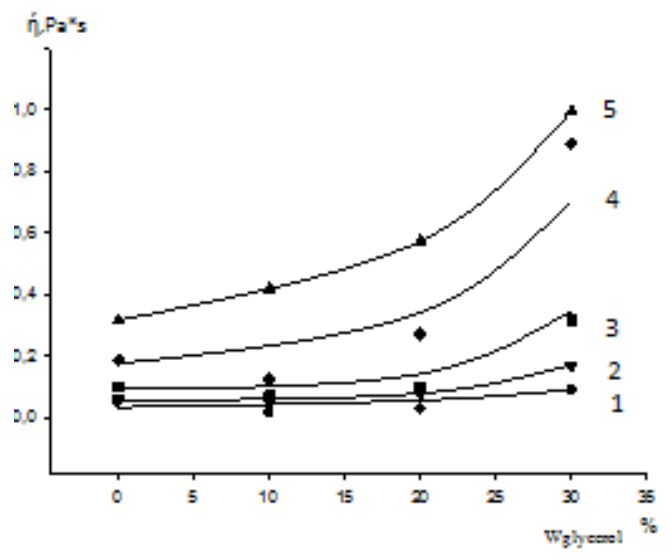

Fig. 2. Dependence of dynamic viscosity of $\mathrm{CHTZ}$ solutions on glycerol content (vol. \%) in acetic acid-water-glycerol solutions; acetic acid concentration in the soluton is $1 \mathrm{wt} \%$. CHTZ concentration (wt \%) is 0.2 (1); 0.4 (2); 0.6 (3); 0.8 (4) and $1(5)$

The elasticity modulus $(G$ ') and the viscosity modulus $(G$ ') of CHTZ solutions

Table 1 in the mixtures $0.1 \%$ acetic acid-glycerol

\begin{tabular}{|l|c|c|}
\hline & $G^{\prime}, \mathrm{Pa}$ & $G^{\prime \prime}, \mathrm{Pa}$ \\
\hline CHTZ in a mixture of 0.1\% acetic acid:glycerol (90:10 v/v) & 2.5 & 2.8 \\
\hline CHTZ in a mixture of 0.1\% acetic acid:glycerol (80:20 v/v) & 8.0 & 4.0 \\
\hline CHTZ in a mixture of 0.1\% acetic acid:glycerol (70:30 v/v) & 13.0 & 9.0 \\
\hline
\end{tabular}

Notes: frequency of oscillating voltage is $1 \mathrm{~Hz}$; CHTZ concentration in solutions is $1 \mathrm{wt} \%$; the voltage amplitude is $1 \mathrm{~Pa}$.

The elasticity modulus $(G$ ') and the viscosity modulus $(G$ ') of CHTZ solutions in the mixtures $0.1 \%$ acetic acid-ethanol

\begin{tabular}{|l|c|c|}
\hline & $G^{\prime}, \mathrm{Pa}$ & $G^{\prime}, \mathrm{Pa}$ \\
\hline CHTZ in a mixture of 0.1\% acetic acid-ethanol (90:10 v/v) & 4.3 & 2.1 \\
\hline CHTZ in a mixture of 0.1\% acetic acid-ethanol (80:20 v/v) & 2.0 & 0.4 \\
\hline CHTZ in a mixture of 0.1\% acetic acid-ethanol (70:30 v/v) & 11.0 & 9.0 \\
\hline
\end{tabular}

Notes: frequency of oscillating voltage is $1 \mathrm{~Hz}$; CHTZ concentration in solutions is $3 \mathrm{wt} \%$; the voltage amplitude is $1 \mathrm{~Pa}$. 


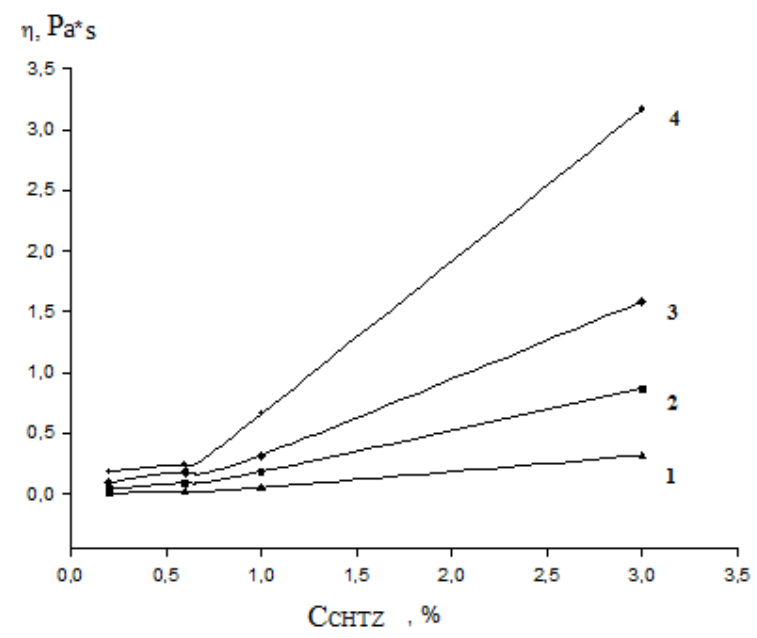

Fig. 3. Dependence of dynamic viscosity of CHTZ solutions in acetic acid-water-ethanol solutions in comparison with CHTZ

in acetic acid on the polymer concentration. Acetic acid concentration is $1 \mathrm{wt} \%$. The ratio $1 \%$ acetic acid:ethanol (v/v) is $90: 10(1) ; 80: 20(2)$ and 70:30 (3)

Secondly, if we add ethanol in $0.1 \%$ CHTZ solution, the acetic acid is accompanied by a significant increase in the dynamic viscosity of the entire range of polymer concentrations (Fig. 3). Moreover, as in the case of glycerol addition, the more the alcohol content in the system, the greater the contribution of the overall elastic component in the viscosity.

Research results of biocompatibility according to hematological parameters showed that in the presence of the studied systems CHTZ-glycerol-1\% acetic acid all total red blood parameters in the groups of experimental animals for the entire postoperative period as a whole were ranged within the physiological norm, and had similar dynamics. After a slight decline during the first week in the period from the $14^{\text {th }}$ to the $30^{\text {th }}$ day, the basic indexes of blood were gradually restoring to the original values, or even exceeded their level. Thus, all the above stated facts allow us to assume that the CHTZ-glycerol systems do not cause oppression of erythropoiesis. Moreover they have a little impact on erythropoietic influence.

\section{Conclusions}

Thus, the structure of CHTZ in the solution is accompanied by the formation of an additional network of physical links, nodes which aggregate CHTZ macromolecules formed in a mixed solvent of acetic acidwater-glycerol or acetic acid-water-ethanol. It promotes earlier formation of viscoelastic properties that ultimately leads to the gelation at lower polymer concentrations than in the case of CHTZ solutions without alcohol addition.
The resulted gelled systems possess a good biocompatibility with hematological indicators, and therefore they can be used as polymeric forms of drugs.

\section{Acknowledgements}

The work was carried out under the financial support of the Ministry of Education and Science of the Russian Federation, task No. 4.5032.2017/CU for the performance of government work in the field of scientific activity within the framework of the basic part of the state task.

\section{References}

[1] Kaplunov I., Pahomov P.: Nanotekhnolohiia. Ekolohiia. Proizvodstvo, 2012, 6, 24.

[2] Valuev L., Davydov D., Sytov D., Valuev I.: Polym. Sci. Ser. A, 2014, 56, 786. https://doi.org/10.1134/S0965545X1406011X [3] Nekrasova T., Andreeva L., Lezov A. et al.: Polym. Sci. A, 2015, 57, 103. https://doi.org/10.1134/S0965545X15020121

[4] Grigor'eva M.: Biotekhnolohiia, 2011, 4, 9.

[5] ZubovV., Pashkin I., Bogachev V.: Pat. RU 2198685, Publ. Febr. 20, 2003.

[6] Philippova O., Korchagina E.: Polym. Sci. A, 2012, 54, 552. https://doi.org/10.1134/S0965545X12060107

[7] Nikonorov V., Ivanov R., Kil'deeva N., Lozinskii V.: Polym. Sci. A, 2011, 53, 1150.

https://doi.org/10.1134/S0965545X1112011X

[8] Kassirski I.: Spravochnik po Funktsionalnoi Diahnostyke. Medicina, Vysshaia shkola, Moskva 1972.

[9] Bazunova M., Valiyev D., Tukhvatullin R., Kulish E.: Scientific and Technical Bulletin of Volga region, 2015, 2, 30.

Received: December 28, 2016 / Revised: January 25, 2017 / Accepted: April 22, 2017

\section{БІОСУМІСНІ ГЕЛЕПОДІБНІ ФОРМИ ЛІКАРСЬКИХ ЗАСОБІВ НА ОСНОВІ РОЗЧИНІВ ПОЛІСАХАРИДУ ХІТОЗАНУ В ПРИСУТНОСТІ СПИРТІВ}

Анотація. Запропоновано підхід до одержання пружно-в'язких систем на основі хітозану без зщиваючих агентів, суть якого полягає у формуванні додаткової сітки фізичних зв'язків внаслідок введення низькомолекулярного модифікатора - етанолу або глічерину. Встановлено, щзо структуроутворення хітозану в розчині супроводжується формуванням додаткової сітки фізичних зв язків, вузлами якоі є агрегати молекул хітозану, сформовані у змішаному розчиннику оитова кислота-вода-глічерин або очтова кислота-водаетанол. Це сприяе скорішому формуванню пружно-в'язкісних властивостей, щчо приводить до гелеутворення за нижчих концентрацій полімеру у порівнянні з розчином хітозану без додавання спирту. Одержсані гелеподібні системи мають задовільну біосуміснсть, і тому можуть використовуватись як полімерні форми лікарських засобів.

Ключові слова: хітозан, гель, спирт, в'язкість, лікарські засоби. 